\title{
Lead Poisoning-Induced Hypertensive Crisis Managed by Prazosin: A Case Report
}

\author{
Bita Dadpour ${ }^{1,2}$, Omid Mehrpour ${ }^{2,3}$, Leila Etemad ${ }^{4}$, Mohammad Moshiri $^{4,}$ \\ ${ }^{1}$ Imam Reza Hospital, Mashhad University of Medical Sciences, Mashhad, IR Iran \\ 2 Addiction Research Centre, Mashhad University of Medial Toxicology, Mashhad, IR Iran \\ 3 Birjand Atherosclerosis and Coronary Artery Research Center, Birjand University of Medical Science, Birjand, IR Iran \\ ${ }^{4}$ Department of Pharmacodynamy and Toxicology, School of Pharmacy, Mashhad University of Medical Sciences, Mashhad, IR Iran \\ ${ }^{*}$ Corresponding author: Mohammad Moshiri, Department of Pharmacodynamy and Toxicology, School of Pharmacy, Mashhad University of Medical Sciences, Mashhad, IR Iran. Tel: \\ 98-5118762615, Fax: 98-5118762615, E-mail: Moshirim881@mums.ac.ir.
}

Received: February 21, 2012; Revised: January 24, 2013; Accepted: April 30, 2013

Introduction: Chronic lead exposure is known to be a risk factor for hypertension (HTN). No specific medication is recommended for the treatment of lead-induced hypertension (LIHTN).

Case Presentation: Our patient was a male admitted with the chief complaint of chronic abdominal pain. His whole blood lead level was reported to be $1961 \mu \mathrm{g} / \mathrm{L}$. He also mentioned a previous history of HTN managed by propranolol (10 mg, TDS). He discharged himself by giving written consent and 19 days later, he was re-admitted due to high blood pressure of 220/140 $\mathrm{mmHg}$. His Blood pressure (BP) was decreased to 180/110 mmHg with sublingual captopril; but, in maintenance therapy, higher doses of captopril could not further decrease BP. Amlodipine was tried which was discontinued due to the patient intolerance. Prazosin was then administered in gradual increasing doses up to $1 \mathrm{mg}$ twice a day and captopril was tapered.

Conclusions:We would like to suggest that LIHTN may better be managed by alpha blockers compared with converting enzyme inhibitors

Keywords: Lead; Hypertension; Prazosin

\section{Introduction}

Lead toxicity is a well-known poisoning since old days. Lead effects on several organs including nervous, cardiovascular, renal, endocrine and hematologic systems ( 1 , 2). Several studies have proven the relationship between body lead content and increasing blood pressure (BP) and also chronic lead exposure is known to be a risk factor for hypertension (HTN) (3). We report a case of leadinduced high BP which was successfully managed by prazosin. This is probably the first report recommending administration of an alpha blocker for the management of lead-induced HTN.

\section{Case presentation}

A 57-year-old man referred to us with chief complaint of chronic constant abdominal pain since one month earlier. He also suffered anorexia, constipation and bloating. On his past history, he mentioned oral opium abuse for almost 15 years. History of HTN and ischemic heart disease was present which had been controlled by administration of propranolol (10 mg, TDS) and sublingual pearl of TNG. During evaluation of his abdominal pain, duodenal ulcer and single tubular rectal polyp were also detected. On admission, his whole blood lead level was reported to be $1961 \mu \mathrm{g} / \mathrm{L}$ and other laboratory tests were as follow: haemoglobin $=10.9 \mathrm{~g} / \mathrm{dL}$, plasma creatinine $=1$ $\mathrm{mg} / \mathrm{dL}$, blood urea nitrogen $=97 \mathrm{mg} / \mathrm{dL}$, aspartate aminotransferase $=63 \mathrm{IU} / \mathrm{L}$, alanine transaminase $=78 \mathrm{IU} / \mathrm{L}, \mathrm{Al}-$ kaline phosphatase $=321 \mathrm{IU} / \mathrm{L}$, serum sodium $=133 \mathrm{mEq} / \mathrm{L}$, and serum potassium $=4.5 \mathrm{mEq} / \mathrm{L}$.

His opium was switched to methadone at dose of $20 \mathrm{mg} /$ day and then tapered. He was treated by EDTA and BAL with the diagnosis of lead poisoning, but the chelating therapy was discontinued because he discharged himself by giving consent form. Nineteen days later, he was re-admitted to our hospital with chest pain without vomiting and diaphoresis. His blood pressure was 220/140 $\mathrm{mmHg}$. After sublingual administration of $50 \mathrm{mg}$ of captopril (two 25-mg tablets) his blood pressure dropped to 180/110 mmHg. On electrocardiography, he had normal axis, sinus rate ( 86 beats/min), and ST depression and inverted $\mathrm{T}$ wave in leads V4-V6. However, cardiac enzymes were within normal limits. He received oral captopril with the dose of $25 \mathrm{mg}$ TDS as well as ASA $80 \mathrm{mg}$ daily. Since his blood pressure did not further decrease, we increased the

Implication for health policy/practice/research/medical education We would like to suggest that LIHTN may better be managed by alpha blockers compared with converting enzyme inhibitors.

Copyright (C 2013, Iranian Red Crescent Medical Journal; Licensee Kowsar Ltd. This is an Open Access article distributed under the terms of the Creative Commons Attribution License (http://creativecommons.org/licenses/by/3.0), which permits unrestricted use, distribution, and reproduction in any medium, provided the original work is properly cited. 
captopril dosage to $50 \mathrm{mg}$ BID and then added another 25 $\mathrm{mg}$ of captopril and $5 \mathrm{mg}$ of amlodipine every day. The patient began to suffer headaches and therefore, amlodipine was discontinued. This time, daily dose of $0.5 \mathrm{mg}$ of prazosin was added to his medications. The response was good and during the next four days, the dosage of prazosin was gradually increased to $1 \mathrm{mg}$ twice a day and captopril was simultaneously tapered. He was discharged with prazosin $1 \mathrm{mg}$ twice a day and blood pressure of 140/70 $\mathrm{mmHg}$. The informed consent was taken from the patient to publish the data on his disease. The ethical committee of Imam Reza hospital approved this report, as well.

\section{Discussion}

Lead is not an essential metal for human physiology and interferes with several cell metabolisms (1). The sources of lead exposure vary in each part of the world. Occupational lead exposure is an important health issue in Iran. Moreover, lead processing industry has always been a major concern since it affects surface water, drinking water, and even the Caspian Sea, the Persian Gulf and the rivers. Meanwhile, lead contamination of air and soil especially in the neighboring of the polluted and industrialized cities is another health issue in Iran. Even foods such as fish, rice, milk, and vegetables- which are the most common food of Iranian people- are contaminated with lead (4, 5). Adulteration of opium with lead and thalium is also widespread in our country (5-7). Based on our previous cases in Mashhad (7), we assumed that the only source of lead exposure in our case was opium abuse. There are many papers published about adverse effect of lead on human organs.Moreover, the relationship between blood lead levels and blood pressure has previously been established by several studies. In a 4-year follow-up study (1997-2001) of Korean lead workers, an annual rise of 10 $\mu \mathrm{g} / \mathrm{dL}$ in blood lead levels was associated with $0.9 \mathrm{mmHg}$ rise in systolic blood pressure (8).

LIHTN may be developed by several mechanisms including I: nitric oxide deficiency due to inactivation of endogenous nitric oxide by reactive oxygen species (9); II: increasing activity of sympathetic and circulating noradrenaline joined with decreasing vascular $\beta$ adrenergic receptor density (10); and/or III: increasing angiotensin converting enzyme (ACE) activity and elevating rennin, angiotensin II, and aldosterone levels of plasma (11). Elevated plasma renin activity is found after periods of modest exposure although activity may decrease to normal or lower in chronic severe exposure.(12) Other mechanisms include heightening of the kininase I and kininase II activities, possible increases in endothelin and thromboxane production, and rise in cellular $\mathrm{Na}+$ and hence $\mathrm{Ca} 2+$ stores of vascular smooth muscles due to lead inhibition of Na-K+ATPase (13). We would like to suggest that chronic lead poisoning was a reason of HTN in this case. When he came back with chest pain, his blood pressure decreased by sublingual captopril and TNG IV drips. But maintenance therapy with captopril could not further decrease blood pressure. According to what mentioned above, although the activity of rennin system may increase at the early stage of LIHTN, it my decrease to normal level over the time (12). This may be the reason for inadequate response to captopril, an angiotensinconverting enzyme inhibitor. One of the most important mechanisms of LIHTN is intracellular Ca2+ increase secondary to Na-K+ ATPase inhibition. We, therefore, added amlodipine, a calcium channel blocker, to his medications which was later discontinued due to adverse effects and patient's intolerance.

On the other hand, lead not only could increase the activity of sympathetic and circulatory noradrenaline- a powerful vasoconstrictor- but also might decrease the vascular $\beta$, e.g. the effective arterial vasodilator. It therefore seems that one of the important mechanisms of LIHTN is the increase in the vascular tone. According to this hypothesis, we changed captopril to prazosin- an alpha adrenergic blocker- with the dose of $1 \mathrm{mg}$ BID, which successfully managed the patient's HTN. In conclusion, we would like to suggest that accelerated HTN due to lead toxicity better responds to alpha blockers compared with converting enzyme inhibitors; however, this hypothesis needs to be further evaluated in future studies.

\section{Acknowledgements}

None declared.

\section{Authors' Contribution}

Bita Dadpour has visited the case and treated him. Omid Mehrpour has revised the end draft. Leila Etemad and Mohammad Moshiri have written the manuscript

\section{Financial Disclosure}

There is no financial disclosure.

\section{Funding Support}

There are no funding or supports.

\section{References}

1. Philip AT, Gerson B. Lead poisoning--Part I. Incidence, etiology, and toxicokinetics. Clin Lab Med.1994;14(2):423-44.

2. Karimi G, Moshiri M, Etemad L. Review of Cases of Lead Poisoning From Opium Abuse In IRAN. Pharmacol online. 2009;3:897-905.

3. Martin D, Glass TA, Bandeen-Roche K, Todd AC, Shi W, Schwartz BS. Association of blood lead and tibia lead with blood pressure and hypertension in a community sample of older adults. $\mathrm{Am} J$ Epidemiol. 2006;163(5):467-78.

4. Mehrpour O, Karrari P, Abdollahi M. Chronic lead poisoning in Iran; a silent disease. Daru. 2012;20(1):8.

5. Karrari P, Mehrpour O, Abdollahi M. A systematic review on status of lead pollution and toxicity in Iran; Guidance for preventive measures. Daru. 2012;20(1):2.

6. Afshari R, Megarbane B, Zavar A. Thallium poisoning: one additional and unexpected risk of heroin abuse. Clin Toxicol (Phila). 2012;50(8):791-2.

7. Afshari R, Dadpour B, Moshiri M, Etemad L. Lead toxicity due 
to opium addiction, a case series. 11th Internatinal congress of Iranian society of Toxicology; 2011; Mashhad, Iran. Iranian j basic med sci; 2011.

8. Glenn BS, Bandeen-Roche K, Lee BK, Weaver VM, Todd AC, Schwartz BS. Changes in systolic blood pressure associated with lead in blood and bone. Epidemiology. 2006;17(5):538-44.

9. Vaziri ND, Khan M. Interplay of reactive oxygen species and nitric oxide in the pathogenesis of experimental lead-induced hypertension. Clin Exp Pharmacol Physiol. 2007;34(9):920-5.

10. Chang HR, Tsao DA, Yu HS, Ho CK. The change of beta-ad- renergic system after cessation of lead exposure. Toxicology. 2005;207(1):73-80.

11. Patrick L. Lead toxicity part II: the role of free radical damage and the use of antioxidants in the pathology and treatment of lead toxicity. Altern Med Rev. 2006;11(2):114-27.

12. Henretig FM. LEAD. In: Nelson LS, Lewin NA, Howland MA, Hoffman RJ, al. e, editors. Goldfrank's Toxicologic Emergencies. New York: MacGrawHill; 2011. p. 1270.

13. Vaziri ND, Sica DA. Lead-induced hypertension: role of oxidative stress. Curr Hypertens Rep. 2004;6(4):314-20. 